GALAXY FORMATION 


\section{Galaxy Formation}

\section{A Personal View}

John Gribbin

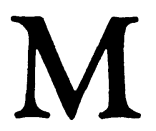


(C) J. R. Gribbin 1976

Softcover reprint of the hardcover 1st edition 1976

All rights reserved. No part of this book may be reproduced or transmitted in any form or by any means, without permission

This book is sold subject to the standard conditions of the Net Book Agreement

First published 1976 by

THE MACMILLAN PRESS LTD

London and Basingstoke

Associated companies in New York Dublin

Melbourne Johannesburg and Madras

SBN 333193679 (hard cover)

SBN 333195124 (paper cover)

ISBN 978-0-333-19512-3

ISBN 978-1-349-15657-3 (eBook)

DOI 10.1007/978-1-349-15657-3

The paperback edition of this book is sold subject to the condition that it shall not, by way of trade or otherwise, be lent, re-sold, hired out, or otherwise circulated without the publisher's prior consent in any form of binding or cover other than that in which it is published and without a similar condition including this condition being imposed on the subsequent purchaser. 
For my bro, molesworth 2 


\section{Introduction}

No-one with an interest in science could fail to notice that astronomy is an area where great advances are being made; but the rapid progress and exciting developments occurring should not conceal the fact that we still have many more questions to ask than answers to give when it comes to dealing with the structure and origin of the Universe in which we live.

In keeping with the rapid development of knowledge about the Universe in the third quarter of the twentieth century, there have been many attempts to propose theories which can embrace all the evidence so far discovered. Some have fallen by the wayside, others have been modified in the light of later developments, but none has remained unchanged in the face of critical discussion and new observational evidence.

With this in mind I feel that there is a place for a book presenting a personal view of galaxy formation in the expanding Universe, giving something of the flavour underlying this activity in an area where the cement of scientific progress has yet to set. My intention is to provide a book which will be useful to the second-year student of physics whether or not his course includes some mention of astrophysics specifically. I hope that I may also reach a wider audience, and that any scientifically literate person will be able to gain some idea of what this rapidly changing subject is about, and of the exciting debate which surrounds it.

This is not meant to be a conventional textbook; there are many better astrophysical texts than I could write already available. But as a journalist who has also been involved in astrophysical research I feel that the conventional textbook approach is not always the most apposite when it comes to putting across ideas. An occasional detour from the traditional path can do much to fill in details of the surrounding scenery not always visible from the high-road.

With this in mind, I have deliberately followed a path here which 


\section{Introduction}

reflects the development of my own interests, including an early flirtation with the steady-state theory as a rather unusual entrance into the realms of general relativity. The fact that, with regret, I can no longer accept the viability of this theory will serve, perhaps, as a cautionary tale for anyone who may be tempted to commit themselves to one or another of the many theories now prevalent.

John Gribbin 


\section{Contents}

Introduction

1. Stars and Galaxies 1

2. Cosmology: The Expanding Universe 7

3. The Traditional Approach: Turbulence and Gravitational Instability

4. Layzer's Gravitational Clustering Hypothesis 23

5. Ambartsumian's Fragmentation Hypothesis 28

6. Continual Creation 32

7. Newtonian Cosmology and Jeans' Criterion 39

8. The Retarded Core Hypothesis 46

9. The Growth of Irregularities in an Expanding Universe 52

10. Evolution of Galaxies 58

11. Our Galaxy 64

12. The Present Balance and Future Prospects 68 References and Further Reading $\quad 73$

$\begin{array}{ll}\text { Index } & 77\end{array}$ 